\title{
Melihat Latar Belakang Australia dalam Memberikan Bantuan Luar Negeri ke Kawasan Pasifik
}

\author{
Yusuf Rifaldy \\ UIN Syarif Hidayatullah Jakarta
}

\begin{abstract}
ABSTRAK
Australia merupakan negara pemberi bantuan luar negeri dengan jumlah terbesar terhadap negara-negara di Kawasan Pasifik. Selain karena faktor kedekatan lokasi geografis, terdapat berbagai faktor lain yang menyebabkan Australia memberikan bantuan luar negeri terhadap Kawasan Pasifik. Kawasan Pasifik yang terdiri dari negara-negara kecil dan sebagian besar merupakan negara kepulauan dengan tingkat ekonomi yang rendah memiliki ketergantungan yang tinggi terhadap bantuan luar negeri yang diberikan oleh negara lain. Kajian ini dilakukan untuk melihat latar belakang Australia dalam memberikan bentuan luar negeri terhadap negara-negara di Kawasan Pasifik serta apa yang dihasilkan dan dicapai dari pemberian bantuan luar negeri tersebut. Kajian ini menggunakan pengumpulan data berbasis literatur, baik menggunakan dokumen resmi yang dikeluarkan oleh pihak yang terkait dengan masalah bantuan luar negeri Australia maupun dokumen-dokumen terkait lainnya. Hasil yang diperoleh dari kajian ini adalah bahwa Australia memberikan bantuan luar negeri terhadap negara-negara di Kawasan Pasifik tidak lepas dari usaha Australia dalam mendapatkan kepentingan nasionalnya, baik dalam hal keamanan, ekonomi, maupun politik.
\end{abstract}

Kata-kata Kunci: Bantuan Luar Negeri, Kepentingan Nasional, Australia, KawasanPasifik

Australia is one of the largest foreign assistance donor country to the countries in the Pacific Region. Besides the proximity of geographic location between the two, there are various other factors that cause Australia to provide foreign assistance to the Pacific Region. The Pacific region which consists of small countries and mostly an island nation with a low economic level has a high dependence on foreign aid provided by other countries. This study was conducted to look at Australia's background in providing foreign assistance to countries in the Pacific Region and what was generated and achieved from the provision of foreign assistance. This study uses literature-based data collection, both using official documents issued by parties related to Australia's foreign aid issues and other related documents. The results obtained from this study are that Australia provides foreign assistance to countries in the Pacific Region that cannot be separated from Australia's efforts to obtain its national interests, both in terms of security, economy, and politics.

Keywords: Foreign Aid, National Interest, Australia, the Pacific Region 
Pemberian bantuan luar negeri yang eksis hingga masa ini berkembang semenjak akhir 1940-an dimana terdapat program yang bernama Marshall Plan untuk membantu memulihkan keadaan ekonomi negara-negara di dunia yang hancur setelah mengalami masa perang (Dornan dan Pryke 2017). Dalam perkembangannya, bantuan luar negeri menjadi suatu instrumen dalam memenuhi kebutuhan modal dan mendorong pertumbuhan di sebuah negara pada 1960-an hingga awal 1970-an (Dornan dan Pryke 2017). Perkembangan pemberian bantuan luar negeri hingga saat ini tidak lepas dari tujuan untuk kemanusiaan juga sebagai sebuah bentuk untuk mendorong tercapainya kepentingan nasional negara pemberi bantuan (Lowy Institute, 2014). Australia merupakan salah satu negara yang sejak lama telah memberikan bantuan luar negeri (Wulandari 2007) yang dikenal sebagai Australian AID. Bantuan luar negeri Australia tersebut banyak yang tertuju ke berbagai negara di berbagai kawasan, seperti ke kawasan Pasifik. Kawasan Pasifik, terutama Pasifik Selatan, merupakan "tetangga dekat" Australia berdasarkan letak dan posisi geografis keduanya (Brown 2012).

Sebagai negara dengan letak yang berdekatan dengan kawasan Pasifik, Australia perlu menjaga kepentingan nasionalnya yang didukung oleh stabilitas dan keamanan di kawasan. Jika terjadi ketidakstabilan di kawasan ini, hal tersebut akan mengganggu kepentingan nasional Australia sesuai dengan yang pernah disampaikan oleh John Howard, salah satu Perdana Menteri Australia (Wulandari 2007).

"It is in Australia's interests and in the interests of our Pacific Island neighbors to strive for a region that is economically viable, politically stable and free from crime. The financial costs and potential threats to Australia from failing states, including transnational crime and international terrorism, would be immense." (Brown 2012)

Negara-negara di kawasan Pasifik terutama negara dengan luas relatif kecil tidak memiliki sumber ekonomi yang cukup untuk berkembang. Hal ini yang menyebabkan bantuan luar negeri seperti Australian sebagai bahan bakar pertumbuhan dan perkembangan ekonomi mereka (Dornan dan Pryke 2017). Bantuan-bantuan yang diberikan Australia terhadap negara-negara di Kawasan Pasifik meliputi dukungan terhadap pembangunan berkelanjutan, keamanan dan pertahanan, pengembangan sistem dan hukum, serta manajemen terhadap perekonomian mereka (Brown 2012). Pemberian bantuan luar negeri Australia terhadap negara-negara di kawasan Pasifik dan negara-negara juga memiliki kepentingan 
untuk menyebarkan pengaruhnya, baik dalam lingkup regional maupun internasional (Moores 2018).

Dalam kasus Australia bantuan luar negeri yang diberikan dapat menjadi aset sebagai penyebaran pengaruh dan membantu membangun soft power mereka di dunia internasional. Hal ini karena dengan membangun soft power dan pemberian bantuan luar negeri memiliki hasil yang serupa meskipun memiliki fokusnya berbeda (Moores, 2018). Adanya pemberian bantuan ini akan membuat negara penerima dapat membangun dan mengembangkan negaranya ke arah yang positif, sehingga kemiskinan maupun isu-isu yang ada dapat lebih berkurang dan teratasi. Berdasar hal tersebut maka dapat terjalin hubungan saling menguntungkan antara negara penerima dengan negara yang memebrikan bantuan. (Moores 2018).

Karena semakin banyak negara yang memberikan bantuan luar negeri dan meningkatkan jumlah yang diberikan, penting bagi Australia untuk tetap mempertahankan kepentingan nasionalnya melalui pemberian bantuan luar negeri ke kawasan Pasifik. Hal ini juga akan memastikan hubungan Australia dengan negara-negara di kawasan Pasifik yang telah terjalin cukup lama dan berlangsung cukup baik dapat terus berlangsung. Selain itu, pemberian bantuan luar negeri ini juga dapat menjadi penanda eksisnya pengaruh Australia di kawasan tersebut. Selebihnya, tulisan ini akan mencoba menguak berbagai alasan dibalik tetap diberikannya bantuan luar negeri Australia kepada negara-negara di kawasan Pasifik.

\section{Arti Penting Pemberian Bantuan Luar Negeri Australia Kepada Negara-Negara Kawasan Pasifik}

Terdapat banyak perspektif mengenai alasan dibalik sebuah negara memberikan bantuan luar negeri terhadap negara lain. Perspektif realis memberikan argumen bahwa pemberian bantuan luar negeri dilakukan sebuah negara untuk mendukung kepentingan nasionalnya. Hal ini tidak lepas dari cara realis melihat hubungan antar negara di dunia internasional yang bersifat anarki. Karenanya, setiap negara perlu mengembangkan kekuatannya untuk menolong dirinya sendiri. Perspektif realis melihat bahwa pemberian bantuan luar negeri dapat dijadikan sebagai alat diplomatis bagi negara pemberi bantuan untuk mencapai kepentingannya, baik kepentingannya di bidang politik, ekonomi, maupun keamanan (Virgianita et al. 2014). Pernyataan tersebut diperkuat dengan argument dari Carol Lancaster (2007) yang menyatakan bahwa kelompok realis cenderung melihat bantuan luar negeri sebagai 
alat diplomasi yang pragmatis dan merupakan instrumen kekuatan politik (hard-headed diplomacy).

Di lain pihak, perspektif strukturalis melihat bahwa pemberian bantuan luar negeri merupakan alat untuk mengontrol dan mengeksploitasi negara penerima bantuan luar negeri. Hal ini dilakukan dalam rangka menjaga hubungan ekonomi, sosial dan politik yang tidak seimbang antara negara pemberi bantuan luar negeri yang merupakan core country dan negara penerima bantuan luar negeri yang merupakan negara pheriphery (Virgianita et al. 2014). Hal ini dapat disimpulkan dari kemampuan ekonomi negara maju yang jauh lebih tinggi dibanding dengan negara yang masih berkembang maupun negara-negara miskin. Meskipun terkesan memiliki kesamaan dengan perspetif realis, perspektif strukturalis tidak memandang bahwa hubungan antar negara di dunia internasional. Namun, perspektif strukturalis menekankan pada karakteristik perekonomian global yang berfokus pada hubungan dominasi, eksploitasi dan dependensi (Virgianita et al. 2014).

Terdapat beberapa pandangan lain diluar ketiga perspektif tersebut dalam memandang alasan dibalik pemberian bantuan luar negeri sebuah negara. Pandangan pertama dikemukakan oleh John Degnbol Martinussen dan Poul Endberg Pedersen (2003) yang menyatakan bahwa motif dan kepentingan sebuah negara dalam memberikan bantuan luar negeri yaitu karena alasan-alasan moral dan kemanusiaan (humanitarian), keamanan nasional, ekonomi, dan lingkungan. Di lain pihak, Francisco Sagasti (2005) menyebutkan bahwa terdapat tiga motivasi utama sebuah negara memberikan bantuan luar negeri, yaitu sebagai bentuk solidaritas internasional, menjaga kepentingan nasional, dan menjaga barang publik internasional. Jika dilihat dari berbagai perspektif dan pandangan tersebut, dapat dikatakan bahwa pemberian bantuan luar negeri tidak dapat dilepaskan begitu saja dari kepentingan nasional negara pemberi bantuan luar negeri tersebut. Meskipun terdapat berbagai motif lain disamping kepentingan nasional, namun kepentingan nasional negara pemberi bantuan luar negeri tetap memberikan pengaruh yang signifikan terhadap keputusan sebuah negara dalam memberikan bantuan luar negeri.

Dalam konteks Australia, pemberian bantuan luar negeri yang diberikan sudah berlangsung sejak lama. Negara-negara di Asia Tenggara yang hampir seluruhnya masih merupakan negara berkembang merupakan salah satu target pemberian bantuan luar negeri Australia. Terdapat berbagai kepentingan dan alasan lain dari 
pemberian bantuan luar negeri Australia terhadap negara-negara di kawasan ini. Salah satu alasan terkuat pemberian bantuan luar negeri Australia terhadap kawasan ini yaitu dari motif ekonomi dan keamanan. Dalam segi ekonomi, ASEAN yang berpenduduk lebih dari 600 juta jiwa merupakan pasar yang potensial bagi produk-produk Australia. Selain itu, ASEAN merupakan mitra dagang terbesar ketiga Australia dengan persentase sekitar 15\% dari perdagangan luar negeri Australia dan bernilai 46,5 miliar dollar Amerika Serikat pada 2015 (Pramanta et al. 2019). Alasan kedekatan geografis juga menjadi salah satu faktor terpeting dari hubungan antara Australia dengan ASEAN serta faktor pendorong Australia memberikan bantuan luar negeri terhadap negara-negara "tetangga"-nya tersebut.

Senada dengan ASEAN, Kawasan Pasifik juga memiliki letak geografis yang dekat dengan Australia. Hal tersebut menyebabkan terbangunnya hubungan diantara keduanya dan terus berkembang hingga saat ini. Secara ekonomi, negara-negara di Kawasan Pasifik jauh lebih lemah dan lebih miskin dibandingkan dengan negaranegara ASEAN. Hal tersebut juga menyebabkan negara-negara di Kawasan ini menerima bantuan luar negeri dari negara-negara lain. Australia merupakan salah satu negara yang rutin memberikan bantuan luar negeri ke Kawasan ini. Pemerintahan di Kawasan Pasifik dikenal kurang berhasil dalam mengendalikan secara penuh terhadap perbatasan wilayahnya dan rapuh secara ekonomi dan keamanan. Hal ini menyebabkan Kawasan ini rawan sebagai tempat berkembangnya kegiatan kriminalitas internasional, pencucuian uang, imigrasi illegal, penyelundupan senjata, penjualan narkotika, serta kegiatan terorisme (Brown 2012). Hal ini tentunya rawan bagi keamanan wilayah sekitar Kawasan Pasifik, termasuk terhadap keamanan nasional Australia. Oleh karena itu penting bagi Australia untuk meningkatkan keamanan di Kawasan Pasifik untuk menjaga keamanan nasionalnya.

Ancaman bagi keamanan nasional Australia tidak hanya berasal dari dalam negeri. Kemanan nasional Australia perlu untuk memperhatikan ancaman yang juga berasal dari luar negeri. Sebagai wilayah yang memiliki posisi dan letak geografis yang terdekat dengan Australia, keamanan di wilayah Pasifik penting bagi keamanan nasional Australia. Hal ini karena kemanan sebuah negara dapat dipengaruhi oleh situasi keamanan yang terdapat di wilayah sekitarnya. Menurut Barry Buzan, kemanan merupakan sebuah fenomena yang relasional yang mana kemanan suatu negara 
dan kawasan harus dipahami melalui pemahaman terhadap pola saling ketergantungan keamanan diantara negara-negara di kawasan tersebut (Rachmat 2017). Hal tersebut menyebabkan pentingnya pemberian bantuan luar negeri oleh Australia terhadap negaranegara di Kawasan Pasifik di bidang keamanan untuk menunjang keamanan nasional negaranya.

Selain sebagai upaya untuk menjaga kemanan nasionalnya, bantuan luar negeri Australia terhadap Kawasan Pasifik juga dilakukan dalam rangka membangun diplomasi dan perkembangan ekonomi (Wood et al. 2017). Australian Infrastructure Financing Facility for the Pacific (AIFFP) dan Export Finance and Insurance Corporation (EFIC) merupakan dua lembaga yang mendapat alokasi dari bantuan luar negeri Australia ke negara-negara di Kawasan Pasifik (Lowy Institute 2014). Kedua lembaga tersebut jika dilihat sangat berhubungan dengan urusan ekonomi. Dari sana, dapat disimpulkan bahwa fokus Australia dalam memberikan bantuan luar negeri terhadap negara-negara di Kawasan Pasifik juga tidak lepas dari kepentingan nasional Australia dalam bidang ekonominya. Perspektif global dari negara-negara pemberi bantuan luar negeri mengenai bantuan luar negeri tersebut juga banyak yang bergeser menjadi berorientasi pada kepentingan ekonomi.

\section{Sekilas Mengenai Bantuan Luar Negeri dan Bantuan Luar Negeri Australia}

Australian AID merupakan salah satu bentuk bantuan luar negeri yang dikeluarkan oleh negara Australia untuk membantu negaranegara yang ekonominya masih miskin dan berkembang untuk mengatasi berbagai persoalan seperti ekonomi, sosial, lingkungan, juga pembangunan. Marshall Plan yang merupakan bantuan dari Amerika Serikat terhadap negara-negara di Eropa setelah Perang Dunia Kedua untuk membangun kembali perekonomian mereka sering dikatakan sebagai awal mula dari pemberian bantuan luar negeri seperti yang dikenal saat ini. Selanjutnya dibentuk Colombo Plan pada 1954yang difokuskan pada upaya kerjasama pembangunan ekonomi dan sosial di Asia Pasifik (Virgianita et al. 2014). Bentuk bantuan luar negeri semakin lama semakin berkembang dan salah satunya berbentuk bantuan pembangunan (developmental assistance) seperti yang diberlakukan oleh negara-negara anggota Organization for Economic cooperation and Development (OECD) yang diberi nama Official Development Assistance (ODA). ODA tersebut dibentuk oleh OECD pada 1969 (Wells 2015) dan Australia bergabung di dalamnya pada 1971. Pinjaman (loan) dana hibah 
(grants) dan kerjasama teknis (Technical coopeation) merupakan tiga bentuk pendistribusian bantuan luar negeri dalam ODA (Virgianita et al. 2014).

Dasar dari pemberian bantuanluarnegeri Australia adalah pemisahan lembaga pemberi bantuan luar negeri Australia dari lembaga pemberi bantuan luar negeri Inggris pada 1967. Saat itu, lembaga pemberi bantuan luar negeri Australia tergabung dalam badan urusan luar negeri Australia. Kemudian, pada masa pemerintahan Whitlam, tepatnya pada 1974, lembaga pemberi bantuan luar negeri Australia didirikan dengan nama AusAID (Phillips 2014). Selain dari Australian AID atau yang disingkat AusAID, Australia memiliki berbagai lembaga pemberi bantuan luar negeri diluar yang didirikan oleh pemerintah seperti Australian Freedom from Hunger Campaign, Oxfam Australia, CARE Australia, The Australian Council for International Development (ACFID) dan lembagalembaga pemberi bantuan luar negeri lainnya.

Sementara itu, realisasi pemberian bantuan luar negeri yang diberikan oleh negara-negara pemberi bantuan luar negeri belum dapat dikatakan memenuhi target yang ditetapkan. Berdasarkan anjuran yang disetujui dalam Perserikatan Bangsa-Bangsa (PBB) pada 1970 dana bantuan luar negeri yang idealnya dikeluarkan oleh negara-negara dengan tingkat ekonomi yang baik atau negara maju adalah 0,7\% dari Gross National Income (GNI) yang mereka hasilkan. Berdasarkan target tersebut, maka setiap pendapatan nasional sejumlah 100 dollar Amerika Serikat, maka negara-negara pemberi bantuan luar negeri idealnya mengeluarkan sejumlah 7 sen untuk dana bantuan luar negeri mereka. Hal ini sesuai dengan perhitungan dari penerima Nobel bidang ekonomi yang bernama Jan Tinbergen yang bertujuan agar negara-negara penerima bantuan luar negeri dapat mencapai pertumbuhan yang diinginkan (Wells 2015).

Realita pada 2014 hanya terdapat lima negara yang memenuhi target pemberian bantuan luar negeri sebesar 0,7\% dari GNI mereka termasuk didalamnya Denmark, Luxemburg, Norwegia, Swedia dan Kerajaan Inggris. Sementara itu, dana bantuan luar negeri yang dikeluarkan oleh negara-negara OECD hanya mencakup 0,29\% dari GNI mereka atau sebesar 134,38 miliar dollar Amerika Serikat. Persentase pemberian bantuan luar negeri terbesar tercatat pada tahun 1961 yang sebesar 0,51\% dari GNI negara-negara OECD yang pada saat itu senilai dengan 41,65 miliar dollar Amerika Serikat. Jika melihat realistas yang ada di Australia, pada 2016-2017, konstribusi 
Australia terhadap pemberian bantuan luar negeri hanya menyentuh angka 0,22\% dari GNI negara tersebut (Wells 2015). Selanjutnya, pada 2019-2020, angka tersebut kembali turun menjadi o,21\% dari GNI Australia atau senilai dengan 4 miliar dollar Amerika Serikat. Angka tersebut diperkirakan akan turun ke 0,19\% dari GNI Australia pada 2021-2022 (Lowy Institute 2014).

Setelah tahun 2000 hingga 2015, jumlah bantuan luar negeri Australia selalu mengalami kenaikan yang cukup signifikan, bahkan sempat menyentuh angka yang melebih 5 miliar dollar Australia. Namun, jumlah bantuan luar negeri yang diberikan oleh Australia terus mengalami penurunan yang cukup signifikan setelah 2015 . Bahkan diperkirakan angkanya akan turun hingga di bawah 4 miliar dollar Australia seperti yang terlihat pada gambar 1.

\section{Gambar 1. Grafik Penurunan Pemberian Bantuan Luar Negeri Australia}

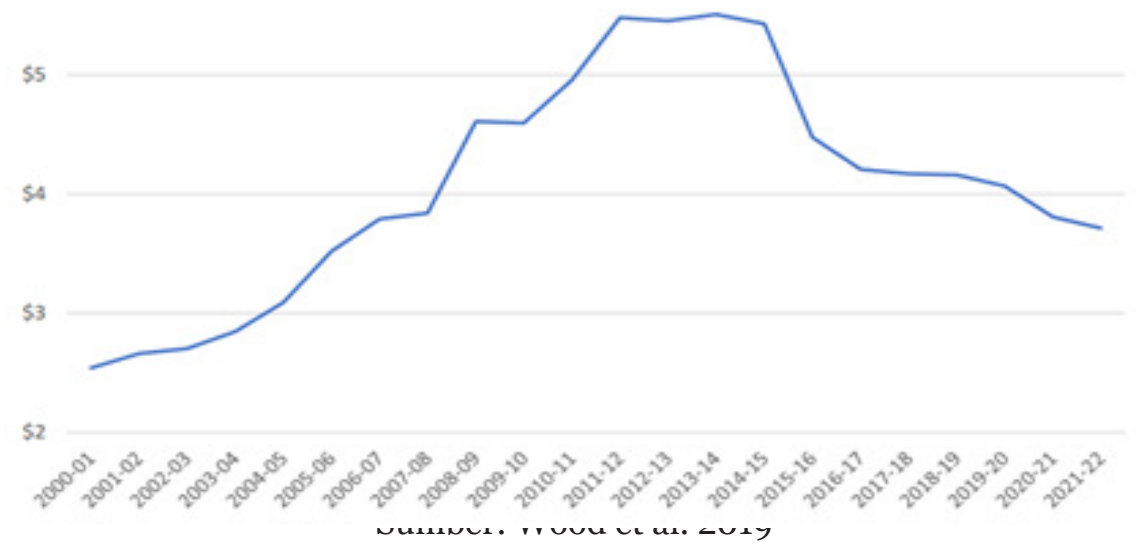

Grafik mengenai penurunan pemberian bantuan luar negeri Australia tersebut menunjukkan bahwa meskipun Australia masih melihat bantuan luar negeri memiliki nilai yang mungkin masih dapat diperjuangkan Australia, namun sudah tidak semenarik sebelumnya disaat Australia menaikkan jumlah bantuan luar negerinya dari tahun ke tahun. Hal ini menunjukkan tantangan baru bagi kelangsungan bantuan luar negeri Australia yang sejak awal belum pernah menyentuh target $0,7 \%$ dari angka GNI mereka dan semakin menurun jumlahnya dalam tahun-tahun mendatang. Dengan berkurangnya bantuan luar negeri yang diberikan oleh salah 
satu negara yang biasanya memberikan bantuan tersebut kepada negara penerima bantuan, maka pertumbuhan dan pembangunan ekonomi negara penerima banuan yang masih bergantung pada bantuan luar negeri akan tersendat dan kemungkinan dapat kembali menghadapi kesulitan yang lebih besar.

\section{Gambar 2. Bantuan Luar Negeri Ke Pasifik Termasuk Timur Leste}

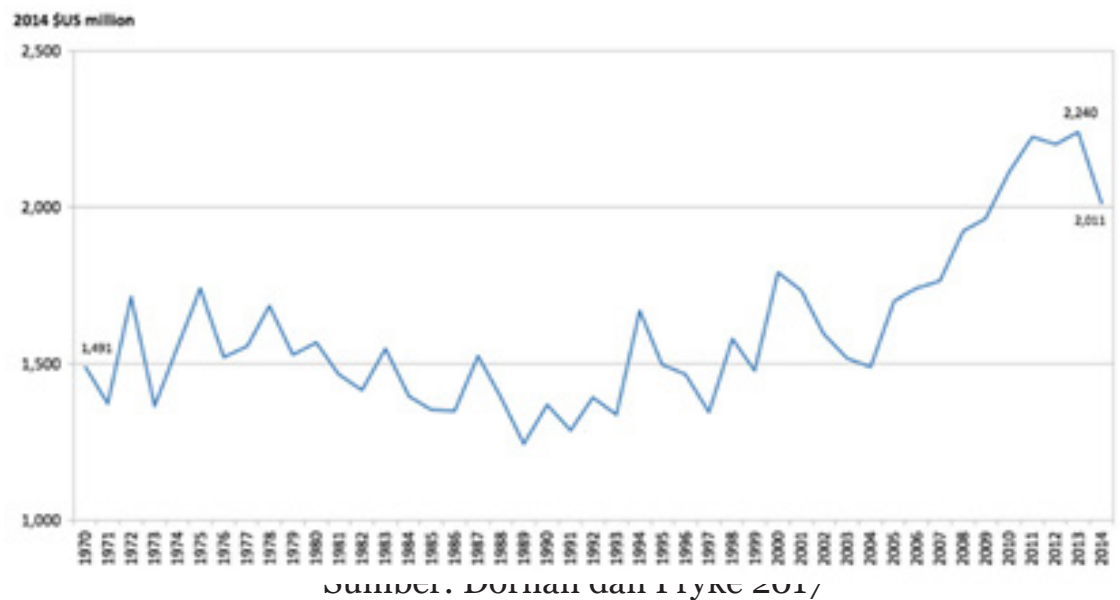

Seperti yang terlihat dalam gambar 2, besaran bantuan luar negeri yang mengalir ke negara-negara di Kawasan Pasifik meskipun tidak selalu menunjukkan kenaikan mengalami penambahan jumlah dari waktu ke waktu. Hal ini dapat dipandang dengan dua kemungkinan, yaitu negara-negara di Kawasan ini sudah dapat lebih mandiri dan mulai tidak terlalu bergantung kepada bantuan luar negeri atau bantuan luar negeri dari negara-negara pemberi bantuan semakin mengurangi jumlah bantuan yang mereka berikan yang menandakan bahwa negara-negara pemberi bantuan luar negeri tersebut tidak lagi menganggap penting pemberian bantuan luar negeri kepada negara-negara berkembang dan miskin untuk memperbaiki kondisi perekonomian mereka. Apabila kondisi yang terjadi sesuai dengan asumsi pertama, maka pemberian bantuan luar negeri terhadap negara-negara di Kawasan Pasifik berhasil dalam memenuhi tujuannya, yaitu membantu negara-negara yang masih berkembang dan miskin untuk dapat mengejar ketertinggalan mereka dari negara-negara dengan perekonomian yang telah maju dan kaya. Namun, apabila yang terjadi merupakan asumsi kedua, maka negara-negara pemberi bantuan luar negeri mengurangi bantuannya karena dianggap tidak penting atau tidak sesuai dengan 
kepentingan nasional yang dikejarnya.

Australia merupakan negara dengan bantuan luar negeri terbesar yang diberikan kepada negara-negara di Kawasan Pasifik. Pada 2012, bantuan luar negeri yang diberikan oleh Australia kepada negara-negara Pasifik sebesar 1,147 miliar dollar Amerika Serikat dan 1,1 miliar dollar Amerika Serikat (Hayward-Jones 2015). Negara pemberi bantuan luar negeri secara bilateral terbesar untuk Kawasan Pasifik selalu didominasi oleh Australia, kemuadian disusul oleh Amerika Serikat, Selandia Baru, Jepang, dan Perancis. Nilai bantuan luar negeri Australia kepada negara-negara di Kawasan Pasifik pada 2012 tersebut senilai dengan 60\% bantuan luar negeri yang diterima negara-negara di Kawasan Pasifik secara bilateral (Hayward-Jones 2015).

Pada tahun 2019-2020, Australia memiliki beberapa program terkait pemberian bantuan luar negerinya di Kawasan Pasifik senilai 1,4 miliar dollar yang meliputi antara lain (Australian Department of Foreign Affairs and Trade 2019): (1) pertumbuhan Ekonomi dengan meningkatkan akses internet dan konektivitas di Papua New Guinea dan Kepulauan Solomon dengan alokasi dana sebesar 200 juta dollar. Selain itu juga dengan membangun ketersedian listrik terhadap 70\% penduduk Papua New Guinea pada 2030 dengan alokasi dana sebesar 100 juta dollar. Adapun dengan penataan kembali pelabuhan di Nauru untuk memastikan keamanan pelayaran dan pengiriman barang dengan alokasi dana senilai 18,25 juta dollar; (2) keamanan dengan memperkuat peran dan kontribusi Pacific Regional Organization melalui dukungan pendanaan dengan alokasi dana sebesar 43,2 juta dollar. Lalu juga memperkuat stabilitas di Kepulauan Solomon dengan menyediakan akses bagi warga negaranya terhadap kepastian hukum dengan alokasi dana sebesar 32,7 juta dollar. Bahkan juga memperkuat ketahanan nasional Kawasan Pasifik terhadap bencana dan pembangunan yang rendah karbon dengan alokasi dana sebesar 300 juta dollar; (3) perhubungan yakni dengan memberikan bantuan Pendidikan terhadap anak-anak di negara-negara Pasifik untuk melanjutkan sekolah menengah melalui beasiswa dan menghadiri sekolah menengah di Australia dengan alokasi dana sebesar 66 juta dollar. Adapun dengan memberikan kesempatan mobilitas yang lebih besar terhadap para pekerja yang berasal dari Kawasan Pasifik, terutama yang berasal dari wilayah kepulauan dengan alokasi dana sebesar 70 juta dollar. Selain itu juga meningkatkan politik, sosial dan ekonomi bagi para wanita di Kawasan Pasifik untuk turut menjadi 
agen perubahan dan pembangunan di Pasifik dengan alokasi dana sebesar 320 juta dollar.

\section{Prospek dari Bantuan Luar Negeri Australia terhadap Kawasan Pasifik}

Bantuan luar negeri yang diberikan oleh Australia terhadap negara-negara di Kawasan Pasifik memberikan dampak yang dapat dilihat. Contohnya adalah membantu Vanuatu dalam mendirikan penyedia jasa layanan telekomunikasi milik pemerintah yang bernama Digicell dan mengakhiri monopoli penyedia jasa layanan telekomunikasi di negara tersebut. Setelah kemerdekaan pada 2002 di Timur Leste, angka kematian bayi yang baru lahir menyentuh angka 110 kematian dari setiap 1.000 kelahiran, sedangkan angka kematian ibu mencapai 700 kematian dari setiap 10.000 persalinan. Hal tersebut menunjukkan layanan dan fasilitas Kesehatan yang kurang memadai di negara tersebut. Dengan bantuan luar negeri yang mengalir ke Timur Leste, baik dari Australia maupun negara lainnya, angka kematian kelahiran dan persalinan menurun hingga dua pertiga dan setengahnya masing-masing (Australian Council for Inernational Development dan Micah 2017). Pemberian bantuan luar negeri yang diterima oleh negara-negara tersebut membantu memberikan pelayanan yang lebih baik terhadap kualitas hidup di negara penerima bantuan tersebut.

Dalam bidang ekonomi dan lapangan kerja, perubahan aturan dari yang sebelumnya menggunakan skema Pacific Seasonal Worker Scheme yang sebelumnya memperbolehkan pekerja dari negaranegara Pasifik untuk mencari pekerjaan di Australia dan Selandia Baru dengan jumlah yang terbatas menjadi lebih fleksibel pada akhir 2018 dan meningkatkan angkanya dari yang sebelumnya hanya sebanyak 2000 orang menjadi sekitar 20.000 orang pada 2019 dan diperkirakan akan mencapai angka 50.000 orang pada 2030. Dalam sebuah laporan, diperkirakan bahwa sekitar 80\% PDB negara-negara di Kawasan Pasifik berasal dari para pekerja migran mereka di luar negeri (Moore 2019). Dengan bertambahnya jumlah pekerja yang berasal dari Kawasan Pasifik di Australia dan Selandia Baru, maka tingkat perekonomian mereka juga akan dapat bertumbuh. Hal ini juga dapat meningkatkan standar kehidupan karena pendapatan yang mungkin diterima oleh para pekerja yang bekerja di Australia maupun Selandia Baru lebih besar dibandingkan dengan di negaranegara di Kawasan Pasifik. Contoh-contoh tersebut menunjukkan bahwa bantuan luar negeri yang diberikan oleh negara-negara pemberi bantuan luar negeri, termasuk Australia terhadap negara- 
negara di Kawasan Pasifik memang memberi dampak yang positif dalam memberikan standar kehidupan yang lebih baik.

Sebagai kawasan yang sebagian besar merupakan wilayah kepualauan, negara-negara di Kawasan Pasifik membutuhkan infrastruktur yang baik untuk menghubungkan pulau-pulau mereka. Terlebih untuk dapat mengakses perdagangan internasional, maka infrastruktur mereka perlu dibangun untuk menunjangnya. Bantuan luar negeri yang diberikan oleh Australia juga memberikan banyak fokus terhadap perdagangan dan infrasturktur bagi negara-negara di Kawasan Pasifik. Hal ini untuk membantu dan mendorong pertumbuhan ekonomi di negara-negara Pasifik dan dalam beberapa cara akan menguntungkan bagi Australia. Dalam pembangunan infrastruktur tersebut, Australia dapat mengambil bagian dalam pembuatan proyek infrastruktur yang akan dibangun. Selain itu, Australia dapat mengambil peran yang lebih besar dalam rantai pasokan bagi negara-negara di Kawasan Pasifik, membuka pasar baru dan lebih luas bagi perusahaan-perusahaan Australia, juga memberikan lebih banyak lapangan kerja dan pemasukan bagi Asutralia dari luar negeri (Howes dan Dornan 2019). Bantuan luar negeri dalam bidang ekonomi ini memang menguntungkan kedua belah pihak, namun pihak yang mendapat keuntungan yang lebih besar bergantung pada kemampuannya dalam memanfaatkan potensi yang dihasilkan oleh pemberian bantuan luar negeri tersebut.

Selain dari efeknya dalam memperbesar soft power yang dimiliki, bantuan luar negeri juga berperan dalam memperkenalkan dan mempromosikan nilai-nilai yang dianut oleh Australia kepada negara-negara penerima bantuan luar negeri mereka. Nilai-nilai tersebut termasuk nilai-nilai rasial, kesetaraan gender, sikap saling menghormati, kebebasan politik, ekonomi dan agama, demokrasi liberal, serta aturan hukum (Moores 2018). Kepentingan nasional Australia terlihat jelas dalam memberikan bantuan luar negerinya terhadap negara-negara di Kawasan Pasifik. Baik dari segi pengaruh, ekonomi, serta keamanan merupakan berbagai pertimbangan Australia dalam memberikan bantuan luar negerinya terhadap negara-negara di Kawasan tersebut. Namun, untuk mencapai hasil yang diinginkan, selain perhitungan tentang kepentingan nasional yang ingin dicapai, perlu dipertimbangkan aspek-aspek lain meskipun berada di luar kepentingan nasional mereka. Selain itu, pemberian bantuan luar negeri dari Australia terhadap negaranegara di Kawasan Pasifik merupakan bentuk komitmen Australia dalam melaksanakan SDGs yang ditargetkan untuk dicapai pada 
2030. Oleh karena itu, aspek kemanusiaan dalam memberikan bantuan luar negeri perlu didorong lebih jauh untuk mengimbangi kepentingan nasional negara pemberi bantuan luar negeri.

\section{Kesimpulan}

Pemberian bantuan luar negeri sebuah negara tidak lepas dari kepentingan nasionalnya, meskipun terdapat berbagai pertimbangan lain seperti aspek kemanusiaan. Kepentingan nasional Australia dalam memberikan bantuan luar negeri ke Kawasan Pasifik terutama dipengaruhi oleh aspek keamanan dan ekonomi. Negara-negara di Kawasan Pasifik yang sebagian besarnya merupakan kepulauan serta memiliki cakupan wilayah yang relatif kecil, menjadikan negara di kawasan Pasifik cenderung untuk bergantung terhadap bantuan dari negara lain. Di bidang ekonomi, Australia memberikan fokus yang besar terhadap perdagangan dan pembangunan dan pemeraaan infrastruktur di Kawasan Pasifik. Hal ini juga tidak lepas dari kepentingan Australia dalam memperluas pasar dan perekonomian Australia dikarenakan Kawasan Pasifik belum mendapat akses yang luas kepada perdagangan internasional. Dalam pembangunan infrastruktur di Kawasan Pasifik, Australia dapat mengambil bagian dalam pembuatan proyek infrastruktur yang akan dibangun. Tidak hanya itu pemberian bantuan ini juga melihat bahwasanya keamanan suatu negara dapat dipengaruhi oleh keamanan dari negara lain. Oleh karena itu, Australia menganggap perlunya meningkatkan keamanan negara-negara disekitarnya guna menjaga pula stabilitas keamanan dalam Australia itu sendiri. Sekalipun diketahui bahwasanya pemberian bantuan luar negeri ini sering dianggap dengan adanya niat terselubung dari negara yang memberi. Namun, perlu dilihat pula dengan adanya bantuan ini sebuah negara akan memiliki hubungan yang baik dengan saling menguntungkan negara satu dengan yang lainnya demi menjaga stabilitas keamanan internasional. 


\section{Daftar Pustaka}

\section{Buku dan Bab dalam Buku}

Hayward-Jones, J., 2015. Australia and Security in the Pacific Islands Region. In Regionalism, Security \& Cooperation in Oceania (pp. 67-78).

Martinussen, J.D., dan Poul, E.P., 2003. Aid: Understanding International Development Cooperation. Zed Books Ltd.

Lancaster, C., 2007. Foreign Aid: Diplomacy, Development, Domestic Politics. the University of Chicago Press.

Virgianita, A., et al., 2014. Perkembangan Diskursus dan Implementasi Bantuan Luar Negeri Dalam Studi Hubungan Internasional Virgianita (Ed.)). Pustaka Sempu.

\section{Jurnal dan Jurnal Daring}

Brown, P., 2012. Australian Influence in the South Pacific. $A D F$ Journal, 189: 66-78.

Dornan dan Pryke, J., 2017. Foreign aid to the Pacific: Trends and developments in the twenty-first century. Asia and the Pacific Policy Studies, 4(3): 386-404. https://doi.org/10.1002/ app5.185

Pramanta, R. A., et al., 2019. Kemitraan Strategis Non-Zero Sum Game: Hubungan ASEAN-Australia dalam Konteks Geopolitik. Indonesian Perspective, 3(2): 111. https:// doi. org/10.14710/ ip.v3i2.22347

Rachmat, A. N., 2017. Dinamika Keamanan Kawasan Asia Pasifik Dalam Persaingan Kekua tan Maritim China Dan Amerika Serikat. Dauliyah Journal of Islamic and Internation al Affairs, 2(2), 131. https://doi.org/10.21111/dauliyah.v2i2.1357

Wulandari, R. D., 2007. Bantuan Luar Negeri Australia dalam Mengatasi Krisis Ekonomi Nauru Tahun 2001-2007. http:// journal.unair.ac.id/download-fullpapers-jahi435d54 b99bfull. pdf

Wood, T., Burkot, C., dan Howes, S., 2017. Gauging change in 
Australian aid: Stakeholder per ceptions of the government aid program. Asia and the Pacific Policy Studies, 4(2): 237-250. https://doi.org/10.1002/app5.173

\section{Publikasi Daring}

Lowy Institute, 2014. Australian Foreign Aid. Issues. [daring]. Tersedia dalam http://www.lowyinstitute.org/issues/ australian-foreign-aid. [Diakses 25 Juli 2020]

Moores, D., 2018. Australian Aid as a Soft Power Asset: Submission to the Australian Government's Soft Power Review World Vision Australia (Issue September). [daring]. Tersedia dalam https://www.worldvision.com.au/docs/default-source/ publications/ government-submissions/australian-aid-as-asoft-power-asset-world-vision-australia\%27s-submission-tothe-soft-power-review.pdf?sfvrsn=fea8cc3c_4. [Diakses 22 Juli 2020]

Phillips, K., 2014. Game of Giving: Australia's history of foreign aid. ABC Radio National. [daring]. Tersedia dalam https://www. abc.net.au/radionational/5340938. [Diakses 25 Juli 2020]

Sagasti, F, 2005. Official development assistance: background, context, issues and prospects (Issue October). [daring]. Tersedia dalam http://dspace.cigilibrary.org/jspui/ handle/123456789/17517. [Diakses 25 Juli 2020]

Wells, B. J, 2015. Foreign Aid And Its Importance In Relieving Poverty. 28(3): 5-8. [daring]. Tersedia dalam https://www. oxfam.org.au/wpcontent/uploads/2015/o9/oxfamforeign-aidgeodate-vol-28-no-3-july-2015.pdf. [Diakses 24 Juli 2020]

Wood, T., Muller, S., dan Howes, S, 2019. Australian aid five years on: the 2018 Australian Aid Stakeholder Survey. [daring]. Tersedia dalam Devpolicy.Org. [Diakses 25 Juli 2020] 
Melihat Latar Belakang Australia dalam Memberikan Bantuan Luar Negeri ke Kawasan Pasifik 